\title{
PNEUMATICI KOTAČA ŠUMSKIH VOZILA
}

\section{TYRES OF FORESTRY VEHICLES}

\author{
Tomislav PORŠINSKY', Josip MATAS², Dubravko HORVAT ${ }^{3}$, Andreja ĐUKA**
}

\begin{abstract}
SAŽETAK
Gume kotača predstavljaju jedini dodir šumskih vozila s podlogom preko kojih se prenose sile, odnosno opterećenja na šumsko tlo, što postavlja zahtjeve pred šumarske stručnjake s ciljem odabira guma pri opremanju vozila na osnovi njihovih dimenzijskih i konstrukcijskih značajki. Osnovne značajke pneumatika obrađene su kroz njihovu konstrukciju, dimenzije i obilježavanje, indeks nosivosti, oznaku brzinske kategorije, tlak punjenja zrakom te dezen gazne površine. Zbog česte povećane vlažnosti šumskih tala te njihove ograničene nosivosti posebna je pažnja posvećena i dodatnom opremanju pneumatika šumskih vozila lancima, odnosno polugusjenicama u cilju smanjenja oštećenja šumskoga tla ili samih pneumatika.
\end{abstract}

KLJUČNE RIJEČI: pneumatik, lanac, polugusjenica

\section{UVOD}

\section{INTRODUCTION}

Kotačje mehanička naprava čijim se okretanjem omogućuje kretanje vozila, a sastoji se od pneumatika koji se postavlja na naplatak. Pneumatik predstavlja zrakom ili dušikom napuhani elastični dio kotača vozila kojega često nazivamo gumom.

Geometrijski gledano pneumatik je torus, odnosno obruč s okruglim prorezom. Mehanički je pneumatik određen kao fleksibilna membranska tlačna posuda, a strukturno je kompozit materijala vrhunskih značajki koji su po kemijskom sastavu duge lančane makromolekule (Intihar 2010).

Wong (2001), kao osnovne zadatke koje pneumatici moraju ispuniti, navodi: 1) podržavanje težine vozila, 2) prijenos obodne i kočione sile kotača na podlogu, 3) upravljanje i promjena željenoga smjera kretanja vozila te 4) amortiziranje vozila pri prelasku preko neravnosti podloge. Drugim rječima, pneumatik treba vozilu osigurati dobro prijanjanje i prijenos uzdužnih i bočnih sila na površinu podloge, uz što manji otpor kotrljanja, dobro prigušivanje vibracija i što manju buku te što veću trajnost.

Nastanku pneumatika prethodilo je otkriće procesa proizvodnje gume 1839. godine, koji je Charles Goodyear nazvao vulkanizacija (Španiček 2011). Prve pneumatike, neovisno jedan o drugome, izradili su i patentirali Robert William Thomson 1845. te John Boyd Dunlop 1888. godine (Španiček 2012).

Cilj je ovoga rada pomoć šumarskim stručnjacima pri izboru pneumatika za šumska vozila, kao i opremanju pneumatika lancima i polugusjenicama.

\section{PNEUMATICI (GUME) TYRES}

Značajke pneumatika bitne za šumarske stručnjake s ciljem odabira guma pri opremanju šumskih vozila, obrađene su kroz sljedeća potpoglavlja: Konstrukcija, Dimenzije i obilježavanje, Indeks nosivosti i oznaka brzinske kategorije, Tlak punjenja zrakom te Dezen gazne površine.

\footnotetext{
Prof. dr. sc. Tomislav Poršinsky, Zavod za šumarske tehnike i tehnologije, Šumarski fakultet Sveučilišta u Zagrebu. Svetošimunska 25, HR - 10000 Zagreb, e-pošta: tomislav.porsinsky@sumfak.unizg.hr

2 Josip Matas, mag. ing. silv., Hrvatske šume d.o.o. - Šumarija Osijek, Ulica Jablanova 13, HR - 31000 0sijek, e-pošta: matas89otok@gmail.com

3 Prof. dr. sc. Dubravko Horvat, Vladimira Filakovca 5, HR - 10000 Zagreb, e-pošta: dhorvat951@gmail.com

${ }^{4 *}$ Korespondencija: Doc. dr. sc. Andreja Đuka, Zavod za šumarske tehnike i tehnologije, Šumarski fakultet Sveučilišta u Zagrebu, Svetošimunska 25, HR - 10000

Zagreb, e-pošta: andreja.duka@sumfak.unizg.hr
} 


\subsection{Konstrukcija - Construction}

Pneumatik vozila, sastoji se od dva osnovna dijela: 1) vanjskog sloja s profiliranom gaznom površinom, ramenom, bokom i stopom gume te 2) karkase i (među)pojasa, koji nose opterećenje kada je guma napuhana (Štrumberger 2005).

Gazna površina (protektor) je vanjski dio pneumatika koji je u izravnome dodiru s podlogom te koji ostvaruje trakciju vozila. Zadatci koje mora ispuniti gazna površina gume su: 1) zaštita karkase od mehaničkih oštećenja, 2) osiguranje prijanjanja pneumatika pri kretanju, kočenju i skretanju vozila te 3) zaštita pneumatika od pretjeranoga trošenja (habanja). Oblik dezena gazne površine i tvrdoća protektora, presudna su dva svojstva pneumatika za ispunjenje navedenih zadataka. Dezen se gazne površine pneumatika sastoji od rebara, blokova, uzdužnih i poprečnih žljebova te lamelastih zareza. Svaki od elemenata dezena ima određenu ulogu u ostvarivanju zadovoljavajućeg prijanjanja pneumatika na podlogu. Uzdužna rebra osiguravaju dobru bočnu stabilnost i sprječavaju bočno klizanje vozila. Kod cestovnih vozila, rebra su razdvojena uzdužnim žljebovima $(3-5 \mathrm{~mm}$ širine, $<20 \mathrm{~mm}$ dubine). Ovi žljebovi služe za odvođenje vode kod dodira gume i kolnika te osiguravaju bolje prijanjanje gume na mokrim kolnicima. Poprečni žljebovi povećavaju elastičnost protektora i omogućuju bolje prijanjanje pri kretanju i kočenju vozila na suhim ili mokrim kolnicima. Na većini dezena postoje i sitni zarezi, čija je uloga da povećavaju elastičnost rebara i blokova. Sitniji dezen s plićim žljebovima osigurava veću učinkovitost pri kočenju na tvrdim i suhim kolnicima.

Krupniji dezeni te širi i dublji žljebovi namijenjeni su za kretanje vozila po cestama s lošom kolničkom konstrukcijom i u zimskim uvjetima.

U žljebovima gazne površine, na nekoliko mjesta po opsegu pneumatika, smješteni su indikatori istrošenosti gume. Zadatak je indikatora pomoć pri donošenju odluke o zamjeni pneumatika na vozilu uslijed njihove istrošenosti, a koji nastupa kada jedan od indikatora dođe $u$ istu ravninu s visinom rebra ili bloka gazne površine.

Rame pneumatika predstavlja blago zaobljen rub između gazne površine i boka pneumatika. Oblik ramena gume predstavlja važan element kontrole cestovnih vozila pri vožnji u zavojima, dok kod radnih strojeva utječe na mogućnost opremanja pneumatika dodatnom trakcijskom opremom.

Bok pneumatika je vanjski tanji gumeni sloj koji se proteže od ramena do stope pneumatika. Osnovna mu je zadaća osigurati čvrstoću na savijanje i uvijanje, odnosno zaštita kordne konstukcije gume (karkase) od trošenja, mehaničkih oštećenja i prodiranja vlage. Na vanjskoj su strani boka gume utisnute reljefne oznake proizvođača pneumatika. Područje boka gume koje obuhvaća dio između točke najveće širine presjeka gume i područja koje pokriva rub naplatka naziva se donji dio boka pneumatika.

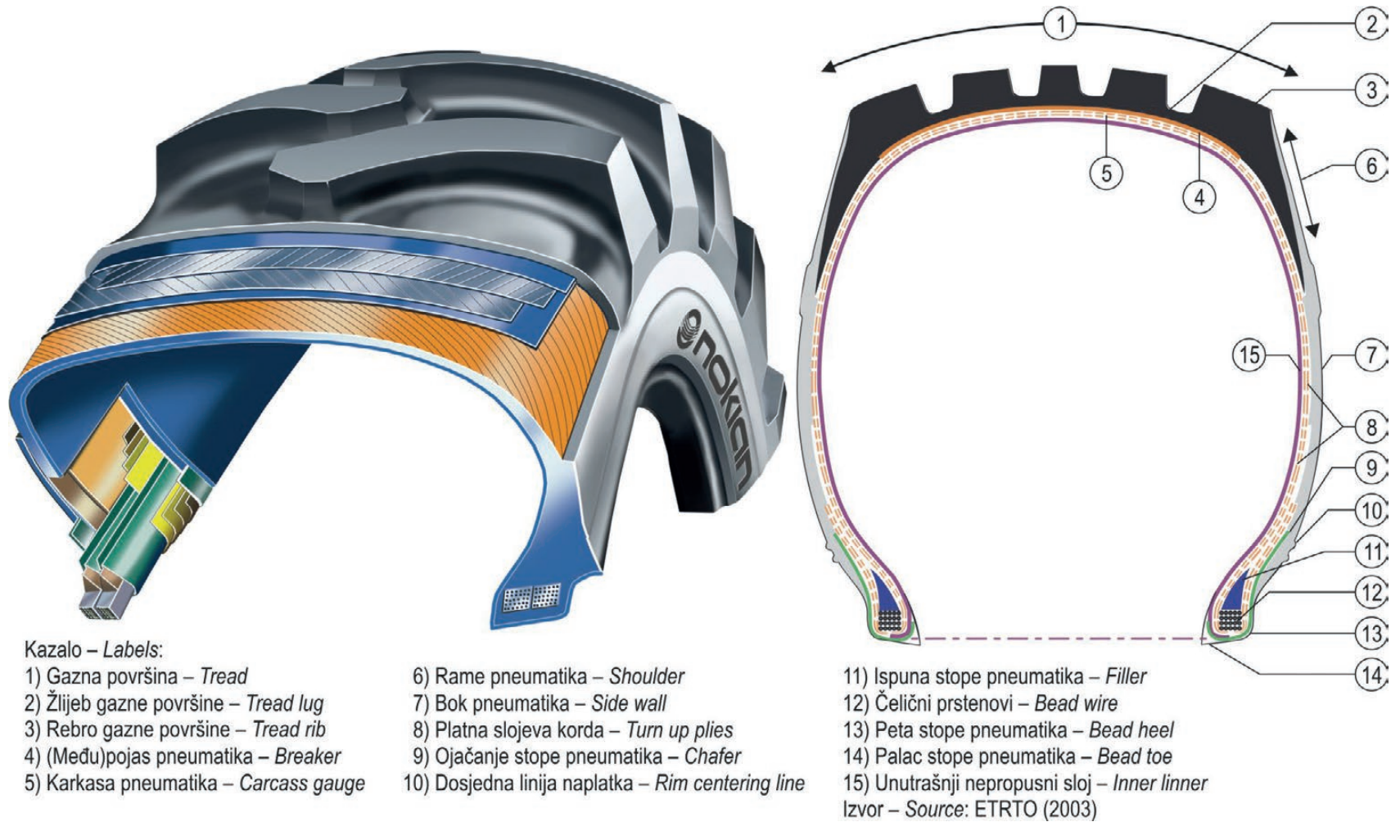

Slika 1. Dijelovi pneumatika

Fig. 1 Parts of tyres 
Stopa je dio pneumatika čiji oblik i konstrukcija omogućuju da se guma prilagodi naplatku i da se na njemu zadrži. Čelični prstenovi (obruči), koji su obloženi tvrdom gumom, u središtu stope osiguravaju radijalnu povezanost pneumatika s naplatkom kotača, omogućuju pravilno sjedanje gume na naplatak i brtvljenje, ali i ukrućenje karkase. Prstenovi mogu biti izrađeni od jedne (debele) ili većeg broja tankih upletenih čeličnih žica, zaštićenih broncom i presvučenih gumom, koje mogu imati kvadratni, kružni, eliptični ili šesterokutni poprečni presjek. Broj žica u čeličnom prstenu, kao i broj prstenova, ovisi prvenstveno o dimenzijama, konstrukciji te samoj namjeni pneumatika (automobili, kamioni, traktori, radni strojevi, ...). Svaki je čelični prsten obavijen gumiranim trakama koje služe za povezivanje s karkasom u bokovima te olakšanu raspodjelu opterećenja u cijelosti pneumatika. Rubovi stope su s vanjske strane obavijeni $s$ više redova debljeg gumiranog platna i predstavljaju ojačanje stope pneumatika koja spriječava koroziju i oštećenja uzrokovana rubom naplatka. Gumene ispune (umetci) stope i doljnjeg dijela boka osiguravaju nagli prijelaz iz krutog područja stope u elastični bok pneumatika. Peta stope predstavlja njen vanjski rub, a palac stope njen unutrašnji rub.

Unutrašnju građu pneumatika čine karkasa i (među)pojas (Štrumberger i Džanić 1991).

Karkasa (kostur) je dio pneumatika ispod gazne površine i boka gume, a sastavljena je od više slojeva platna usporednih niti korda koja su učvršćena na čelične prstenove stope pneumatika. Kord predstavljaju gumirane niti od kojih su sastavljeni slojevi platna karkase. Niti korda mogu biti tekstilne, viskozne, poliamidne ili čelične, a procesom vulkanizacije vlakna korda su gumirana i međusobno slijepljena.
Vlakna korda među slojevima unakrsno su povezana, ali se međusobno ne dodiruju jer bi se trenjem među njima izazvalo zagrijavanje karkase. Karkasa je nosivi, gipki i elastični dio napuhanoga pneumatika, koja preuzima sva opterećenja na istezanje i savijanje, do kojih u pneumatiku dolazi zbog tlaka punjenja zrakom, odnosno prenosi sve sile koje se javljaju pri kretanju, kočenju i upravljanju s kotača, na gaznu površinu pneumatika.

(Među)pojas je gumeno-tekstilni ili češće gumeno-čelični omotač sastavljen od jednog ili više slojeva gradiva, koji se nalazi između gazne površine i karkase te predstavlja njihovu elastičnu vezu. Osim povezivanja gazne površine i karkase, zadatak je pojasa primanje i ublažavanje udaraca kojima je pneumatik izložen pri kretanju vozila po nepravilnostima podloge, odnosno njihovo prenošenje na karkasu gume i samo vozilo. Postavljanjem pojasa po opsegu karkase: 1) uteže se i stabilizira pneumatik prilikom kotrljanja, 2) osigurava se krutost i povećava čvrstoća pneumatika te 3) štiti se karkasa od mehaničkih oštećenja. Pojasevi su tipični za radijalnu konstrukciju pneumatika, a za dodatnu trajnost i veću otpornost pneumatika na bušenje, neki proizvođači ugrađuju u pojaseve vlakna od kevlara.

U prošlosti su tlak zraka u pneumatiku održavale zračnice (eng. Tube Type) - kružne, zatvorene gumene »cijevi« u kojima je bio ugrađen povratni ventil zraka. $U$ današnje vrijeme prevladavaju pneumatici bez unutrašnje gume (eng. Tubeless), koji su s unutrašnje strane obloženi tankim slojem vrlo elastične nepropusne gume, a koji se proteže od stope do stope pneumatika. Prednosti gume bez zračnice su jednostavnija montaža i mala vjerojatnost naglog pada tlaka zraka pri oštećenju pneumatika, ali i jednostavniji popravak probušene gume.
A) Radijalna - Radial (radial-ply)

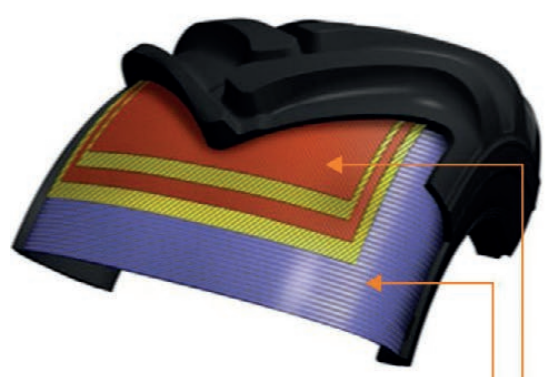

Karkasa gume je stabilizirana nerastezljivim omotačem (pojasom) po obodu. The tyre carcass is stabilized by an inextensible circumferential belt.

Platna su slojeva kordnih niti položena pod $90^{\circ}$ u odnosu na uzdužnu os gaznoga sloja. The ply cords are laid substantially at $90^{\circ}$ to the centerline of the tread.

\section{B) Dijagonalna - Diagonal (bias-ply)}

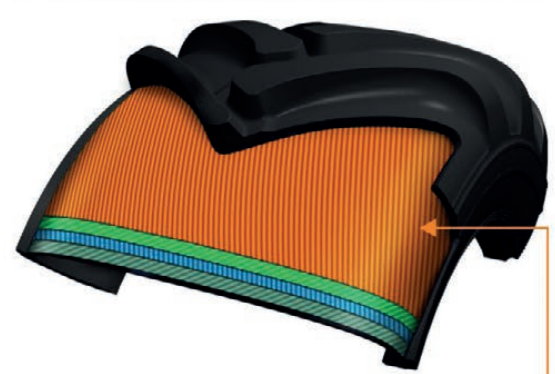

Platna slojeva kordnih niti izmjenjuju svoj položaj pod kutem manjim od $90^{\circ} \mathrm{u}$ odnosu na uzdužnu os gaznoga sloja. The ply cords are laid at alternate angles substantially less than $90^{\circ}$ to the centerline of the tread.

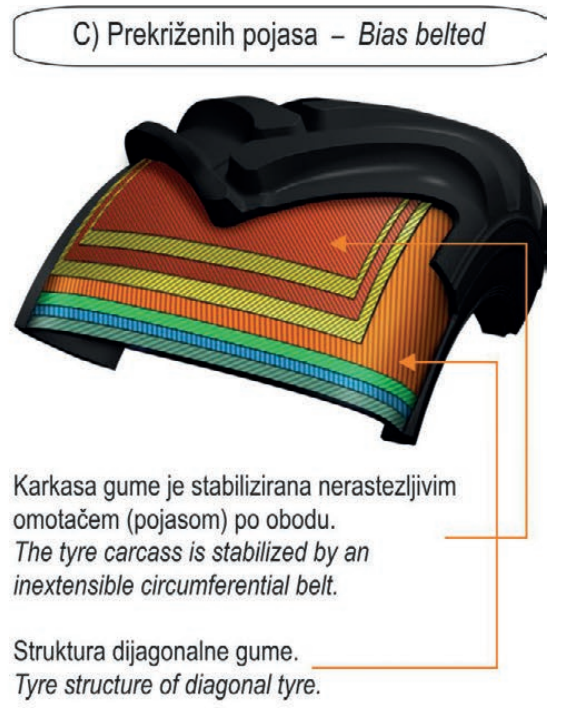

Izvor - Source: Nokian (2017)

Slika 2. Vrste konstrukcija pneumatika

Fig. 2 Types of tyres construction 
S obzirom na kut polaganja kordnih niti u odnosu na uzdužnu os gazne površine, razlikuju se sljedeće tri konstrukcije ili strukture pneumatika: 1) radijalna, 2) dijagonalna te 3) prekriženih pojasa (slika 2).

Radijalna konstrukcija pneumatika je ona kod koje kordne niti dopiru do stope gume i poredane su tako da oblikuju kutove od oko $90^{\circ}$ u odnosu na središnju crtu gaznog sloja i kojem je karkasa stabilizirana kružnim, gotovo nerastezljivim pojasom (Hnatko 1977). Radijalni pneumatici (slika 2A) imaju za razliku od dijagonalnih, nejednak broj niti korda u gaznoj površini i u bokovima, tako da opterećenje nosi manji broj kordnih niti, što ovom tipu pneumatika daje dobru elastičnost. Kod radijalnih guma iznad karkase i neposredno ispod gazne površine nalazi se (među)pojas od korda ili čelika s dijagonanalno upredenim nitima, zbog čega su i dobile i naziv "pojasaste«. (Među)pojas čini više slojeva viskoznog i čeličnog korda, koji su glavni razlog prednosti radijalnih pneumatika. Kordovi su u pojasu smješteni pod malim kutem od 15 do $20^{\circ}$. Pojas se gotovo ne rasteže i stabilizira gaznu površinu tako da dezen (orebrenje) pri kretanju vozila ne mijenja oblik, ali dolazi do savijanja bokova gume. Ovakvom je konstrukcijom pneumatika ostvareno neovisno djelovanje mekih bokova i vrlo tvrdog gaznoga sloja, što omogućava bolje (ravnomjernije) nalijeganje pneumatika na podlogu po kojoj se kreće vozilo te manji otpor kotrljanja i veću uštedu goriva. S gledišta dinamičkih svojstava, posebno je značajno što su radijalni pneumatici znatno otporniji na djelovanje udara pri nailasku kotača na neravnine podloge jer su značajke deformacija takve gume znatno povoljnije, naročito pri većim brzinama kretanja cestovnih vozila. Radijalni pneumatik ima približno kvadratno - pravokutni oblik dodirne površine s ravnomjernim rasporedom dodirnoga tlaka te stabilnu gaznu površinu uz minimalne deformacije pri kretanju. Ovo je posebno važno na mokrim i skliskim kolnicima kada žljebovi gazne površine moraju biti otvoreni kako bi mogli primiti i izbaciti vodu zbog što boljeg dodira pneumatika s kolnikom prometnice. Na mokrim cestama je put kočenja $s$ radijalnim pneumatikom kraći u odnosu na druge vrste konstrukcija guma. Prilikom kretanja vozila u horizontalnim krivinama (zavojima) dodirna površina radijalnoga pneumatika zadržava približno isti oblik, također kao rezultat nezavisnog djelovanja gazne površine i bokova te daje stabilnost gaznoj površini radijalnog pneumatika na podlozi i omogućava da pneumatik zadrži svoju putanju. Elastični bokovi radijalnih pneumatika predstavljaju i nedostatak, uslijed mogućnosti njihovoga iznenadnog oštećenja (bušenja) pri djelovanju oštrog kamenja na slabije bokove ovih guma, što je naročito izraženo kod udvojenih kotača radnih strojeva, kad kameni materijal dospije među njih. Radijalni je pneumatik s čeličnim žičanim jezgrom koncipiran 1946. godine (Michelin) i doveo je do revolucije u proizvodnji pneumatika, što je za posljedicu imalo postu- pno potiskivanje iz upotrebe pneumatika s dijagonalnom konstukcijom na cestovnim vozilima. Radijalni raspored niti karkase daje pneumatiku bolja svojstva u odnosu na dijagonalni, koja se očituju kroz: odlično prijanjanje, bolji prijenos vučne sile, manji otpor kotrljanja (istovremeno smanjuju i potrošnju goriva), veću stabilnost, bolju otpornost na bušenje, veću trajnost uz ravnomjernije trošenje i veću udobnost pri vožnji.

Kod dijagonalne konstrukcije pneumatika, kordne niti dopiru do stope gume i poredane su tako da čine izmjenične kutove manje od $90^{\circ} \mathrm{u}$ odnosu na središnju os gaznog sloja (Hnatko 1977). Drugim riječima, kordne niti kod dijagonalnih pneumatika (slika $2 \mathrm{~B}$ ) postavljene su dijagonalno, tj. ovijaju se oko torusa pod kutem od $\sim 40^{\circ}$. Sljedeće niti korda postavljaju se okomito na prvi sloj (kord), treće okomito na drugi sloj, itd. Između pojedinih slojeva (kordova) postoji sloj gume tako da se kordovi međusobno ne dodiruju. Svi kordovi zajedno čine kostur (karkasu) pneumatika. Broj je niti karkase najčešće između 4 i 16. Dijagonalne niti mogu se postavljati i pod kutem od $\sim 30^{\circ}$ i predstavljaju dijagonalno utegnute ili »S gume«. Karkasa dijagonalnih pneumatika ima jednaku krutost na gaznoj površini i na bokovima te je dosta kruta što pneumatiku daje manju elastičnost pod opterećem kotača, a veću mogućnost da se zbog bočnih sila gubi kontakt na jednome dijelu gazne površine pneumatika. Dijagonalni pneumatik ima približno kružno - eliptični oblik dodirne površine s neravnomjernom raspodjelom dodirnoga tlaka, nestabilnu gaznu površinu uz značajne deformacije pri kretanju, što s gledišta prijanjanja dovodi do gubitka sila (uzdužnih - vučnih i poprečnih - kočionih) i do $60 \%$ većih nego u slučaju korištenja radijalnih guma. Dijagonalni pneumatik, ima manji kontakt s podlogom zbog deformacija boka, ali i gazne površine gume pod djelovanjem bočnoga opterećenja. Navedeno, posebno dolazi do izražaja pri kretanju u zavojima ili mokrim kolnicima, zbog čega su dijagonalni pneumatici kod današnjih cestovnih vozila sve manje u uporabi.

Pneumatici s prekriženim pojasima su dijagonalne konstrukcije, kod kojeg je karkasa ograničena pojasom sastavljenim od dvaju ili više slojeva gotovo nerastezljivih kordnih niti koje čine izmjenične kutove manje od onih što ih čine kordne niti karkase (slika 2C). Ova vrsta konstrukcije pneumatika objedinjava značajke dijagonalne, ali radijalne konstrukcije (Danon i dr. 2014).

\subsection{Dimenzije i obilježavanje - Dimensions and Markings}

Osnovne standardizirane dimenzije na poprečnom presjeku (ne)opterećenoga pneumatika prikazane su na slici 3 , te imaju sljedeće značenje:

$\Rightarrow$ vanjski promjer pneumatika je najveći promjer nove neopterećene i napuhane gume montirane na naplatak, 
$\Rightarrow$ širina gazne površine pneumatika je linearna udaljenost između vanjskih površina dezena pneumatika,

$\Rightarrow$ širina presjeka pneumatika je linearna udaljenost između vanjskih površina stranica napuhane gume, ne računajući reljef koji čine natpisi, ukrasi, zaštitne vrpce ili izbočine (rebra),

$\Rightarrow$ ukupna širina pneumatika je linearna udaljenost između vanjskih površina strana napuhane gume, uključujući natpise, ukrase i zaštitne vrpce ili izbočine,

$\Rightarrow$ širina presjeka opterećenoga pneumatika je linearna udaljenost između vanjskih površina stranica nazivno napuhane i opterećene gume,
$\Rightarrow$ visina presjeka pneumatika je razmak jednak polovici razlike između vanjskoga promjera gume i nazivnoga promjera naplatka,

$\Rightarrow$ nazivni omjer (odnos) oblika je stostruka vrijednost broja dobivena dijeljenjem broja koji izražava visinu presjeka gume s brojem koji izražava nazivnu širinu gume,

$\Rightarrow$ nazivni promjer naplatka je promjer naplatka na koji se postavlja guma,

$\Rightarrow$ širina naplatka je širina naplatka na koji se postavlja guma,

$\Rightarrow$ visina dosjeda naplatka je visina koju ispunjava stopa pneumatika,

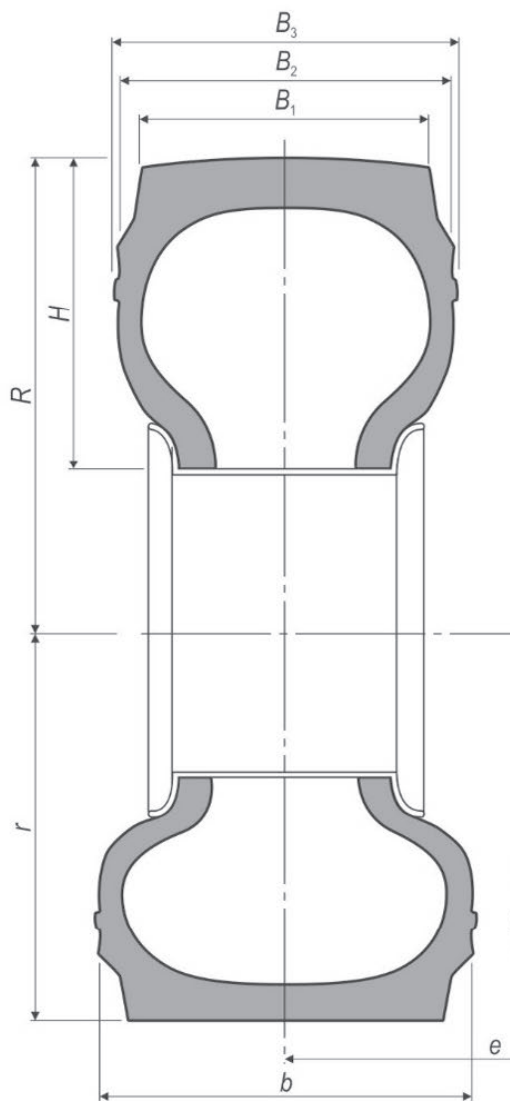

Oznake - Labels:

$B$. Širina gazne površine gume - Tread width

$B_{2}$ Širina presjeka gume - Section width

$B_{3}$ Ukupna širina gume - Overall width

b Širina opterećenog presjeka gume - Loaded section width

$D$ Vanjski promjer gume - Outer diameter

$R$ Polumjer neopterećene gume - Unloaded radius

$r$ Polumjer opterećene gume - Static loaded radius

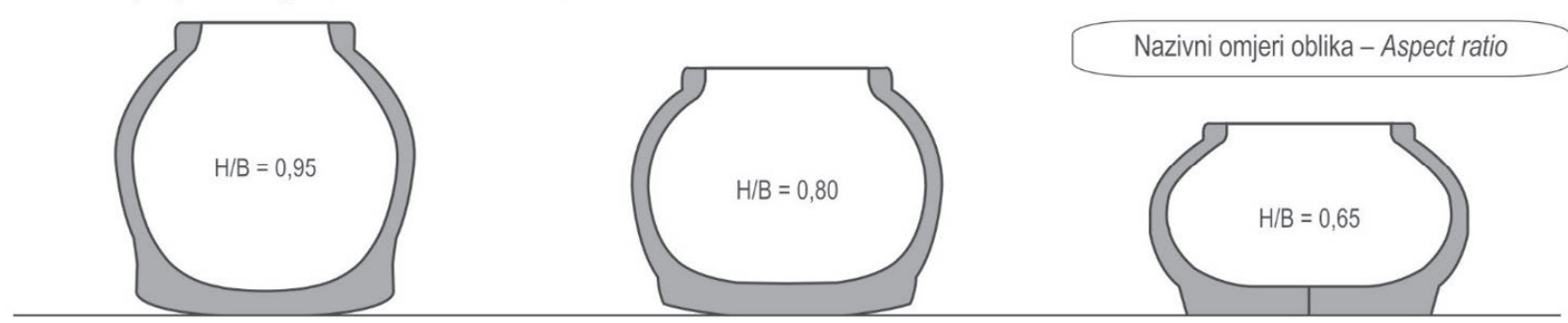

$\delta$ Progib opterećene gume - Deflection under load

H Visina presjeka gume - Section height

d Nazivni promjer naplatka - Nominal rim diameter

W Širina naplatka - Rim width

$h_{\mathrm{f}}$ Visina dosjeda naplatka - Rim-flange height

e Najmanji razmak udvojenih guma - Dual tyre spacing

Slika 3. Dimenzije guma

Fig. 3 Dimensions of tyres 
$\Rightarrow$ statički polumjer neopterećenog pneumatika je razmak između podloge i osi nepokretnog neopterećenog pneumatika koji je montiran na naplatak i napuhan na nazivni tlak zraka,

$\Rightarrow$ statički polumjer opterećenog pneumatika je razmak između podloge i osi nepokretnog nazivno opterećenog pneumatika koji je montiran na naplatak i napuhan na nazivni tlak zraka,

$\Rightarrow$ progib opterećenoga pneumatika je razlika polumjera opterećenog pneumatika i polumjera neopterećenoga pneumatika.

Osim navedenih, postoje i druge dimenzije pneumatika koje mogu biti važne korisnicima vozila, kao što su:

$\Rightarrow$ Dinamički radijus pneumatika, koji predstavlja udaljenost od osi opterećenoga kotača u kretanju do površine podloge. Dinamički radijus pneumatika je uvijek veći od statičkog, a na njegove vrijednosti utječu sile vuče odnosno kočenja.

$\Rightarrow$ Radijus kotrljanja pneumatika je računski pokazatelj koji se izračunava na način da se prijeđena udaljenost za jedan okret kotača podijeli s $2 \pi$. Ovaj je pokazatelj pneumatika utjecan klizanjem kotača.

Horvat (1993) smatra da gume na šumarskim vozilima postaju sve šire (odnos promjera i širine gume $<2$ ), što potvrđuju današnje konstrukcije »šumskih « pneumatika kroz trend povećanja širine i smanjenja visine presjeka.

Pneumatici za motorna i priključna vozila te radne strojeve obilježeni su prema odgovarajućim propisima, kao što su: 1) ECE (Economic Commission for Europe), 2) ETRTO
(The European Tyre and Rim Technical Organisation), 3) DOT (Department of Transport of USA)., ... Cilj je ovih propisa da krajnjim korisnicima vozila osiguraju jasne informacije o pneumaticima koje nabavljaju, odnosno da budu pomoć prilikom njihovoga odabira.

Na boku se pneumatika u skladu s navedenim standardima nalaze sljedeći podatci (slika 4): naziv proizvođača (ili njegov zaštitni znak), komercijalni naziv pneumatika, država porijekla, oznaka dimenzija pneumatika, oznaka strukture (konstrukcije) pneumatika, način izvedbe pneumatika (s ili bez zračnice), najveći dopušteni tlak punjenja zrakom, indeks nosivosti pneumatika, oznaka brzinske kategorije pneumatika, datum proizvodnje, razredbeni kod gazne površine i dr.

Unatoč standardiziranom načinu obilježavanja pneumatika, mnogi njihovi proizvođači ih obilježavaju na različite načine, kao na primjer:

$\Rightarrow 12.4-24$, dijagonalni pneumatik, širine presjeka 12,4 inča za naplatak promjera 24 inča,

$\Rightarrow 22 / 65-25$, dijagonalni pneumatik, širine presjeka 22 inča, nazivni odnos oblika $65 \%$ širine presjeka za naplatak promjera 25 inča,

$\Rightarrow 67 \times 34.00-26$, dijagonalni pneumatik, vanjskog promjera 67 inča te širine presjeka 34 inča za naplatak promjera 26 inča.

S obzirom da su šumska vozila od strane njihovih proizvođača već definirana svojim dimenzijskim i konstrukcijskim značajkama, njihova se kretnost (djelotvornost) može povećati isključivo odabirom vrste pneumatika (u skladu s

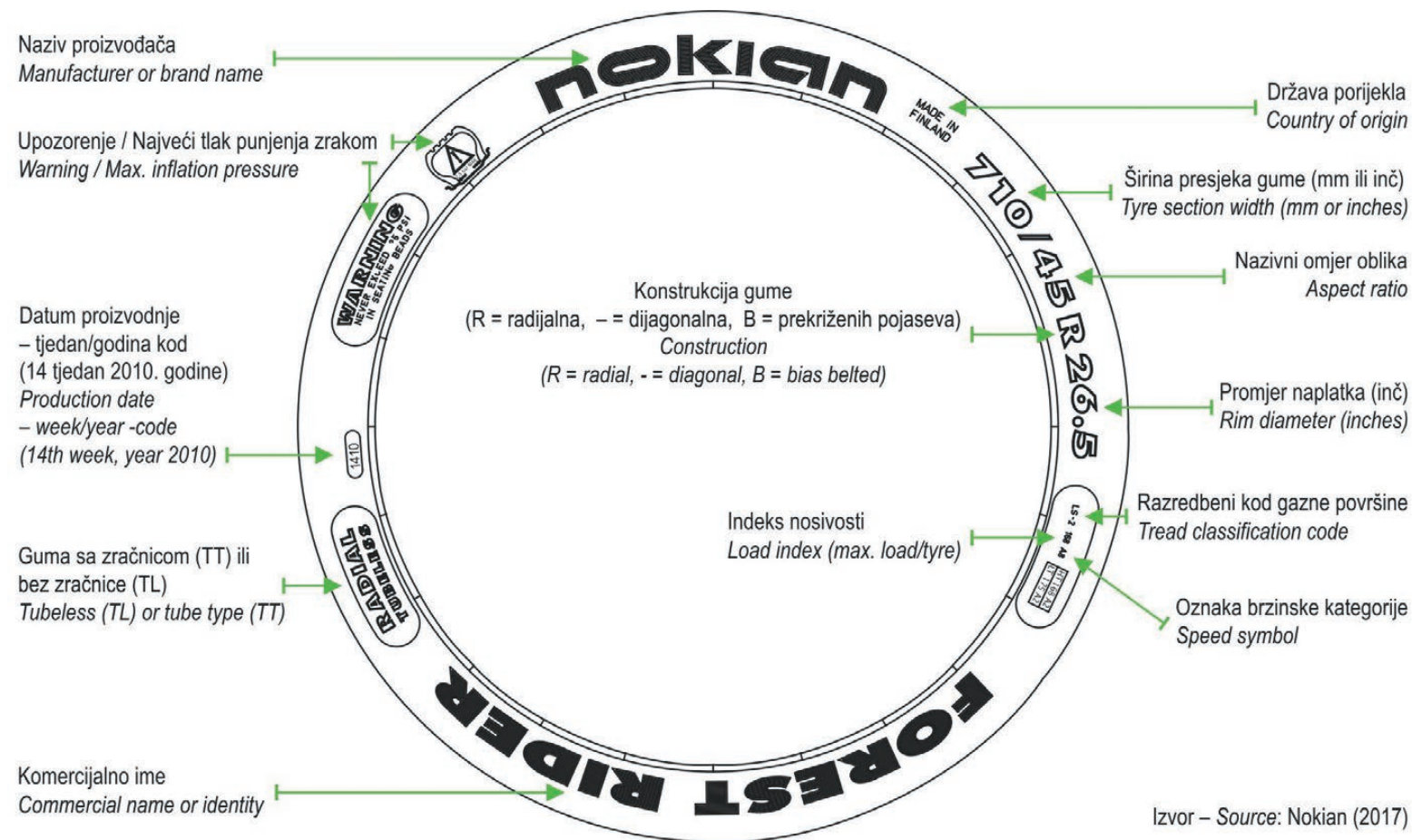

Slika 4. Obilježavanje pneumatika

Fig. 4 Marking of tyres 


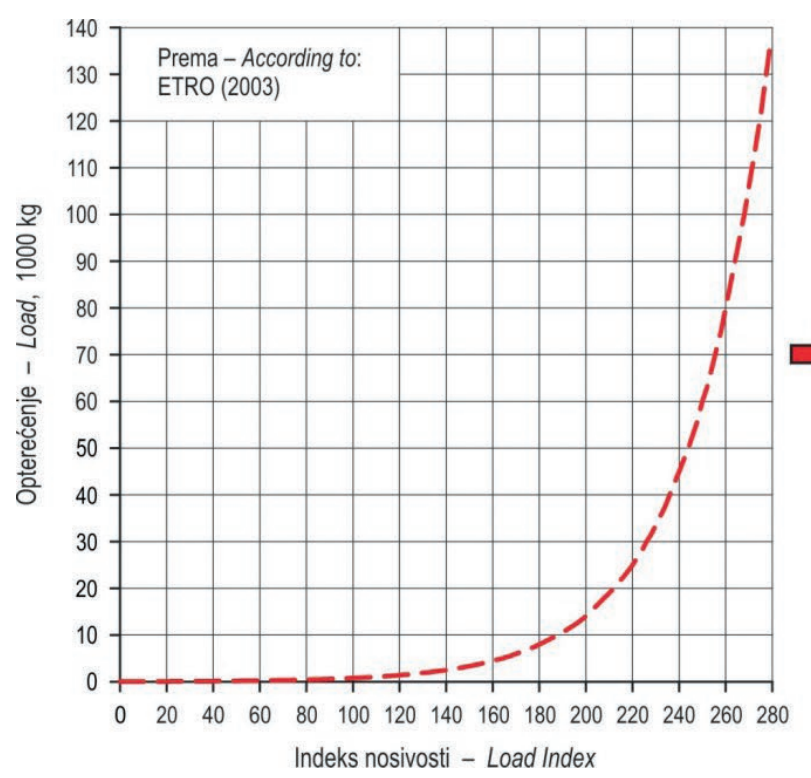

Slika 5. Dijagram indeksa nosivosti

Fig. 5 Diagram of Load Index

naputcima proizvođača) s obzirom na namjenu koju obavljaju, odnosno terenske prilike u kojima se koriste. Izbor užih guma većega promjera povoljno djeluje na kretnost šumskih vozila po nedeformabilnim (suhim) podlogama usljed manjeg otpora kotrljanja i veće brzine kretanja (Križnar 1978), ali istovremeno nepovoljno utječu na porast visine težišta vozila uz narušavanje njegove bočne stabilnosti pri radu na nagnutim terenima te veće sabijajanje tla ograničene nosivosti. Na tlima ograničene nosivosti, $\mathrm{u}$ cilju dosezanja okolišne pogodnosti, svakako prednost imaju šire elastične gume sa nižim tlakovima punjenja zrakom te samim time većim progibom gume i većom dodirnom površinom, uz manje dodirne tlakove i otpore kotrljanja (Cudzik i dr. 2018). Međutim, tlak punjenja guma zrakom ne može se po volji smanjivati zbog uklapanja i držanja gume na naplatku kotača, ali i pojave klizanja stope pneumatika po dosjedu naplatka.

\subsection{Indeks nosivosti i oznaka brzinske kategorije - Load Indeks and Speed Symbol}

Djelotvornost šumskih vozila povezana je s njihovom brzinom kretanja, ali i opterećenjima osovina te kotača vozila. Đuka (2014), razvijajući model prometnosti terena za planiranje privlačenja drva, kao jedan od cijelog niza kriterija kretnosti šumskih vozila navodi i dopušteno opterećenje pneumatika (guma) kotača šumskih vozila, koje deklariraju njihovi proizvođači. Učestalo preopterećenje guma šumskih vozila dovodi do njihovog pojačanog trošenja (habanja) te oštećivanja i/ili pucanja u njihovome uporabnom ili amortizacijskom razdoblju. Čopec i Filipović (2007) istražujući vučne karakteristike traktora s pogonom na sva četiri kotača opremljenog novim i poluistrošenim pneumaticima, utvrđuju smanjenje vučne sile za 18 \% i povećanje potrošnje goriva za 13,6 \% pri radu s poluistrošenim gumama. Vijek uporabe pneumatika šumskih vozila ovisi o namjeni samih vozila (skider, forvarder, harvester,...), odnosno o uvjetima rada (kamenitost/stjenovitost terena, nosivost podloge, opremanje pneumatika vozila lancima ili polugusjenicama, udaljenost privlačenja drva, ...) te se kreće u širokome rasponu od 1500 do 5000 pogonskih sati (FAO 1992).

Dopušteno opterećenje pneumatika (guma) kotača vozila uopće, međunarodno je definirano indeksom nosivosti (slika 5). Indeks nosivosti (eng. Load Index) je brojčana oznaka koja predstavlja najveće dopušteno opterećenje koje guma može podnijeti kod odgovarajućeg tlaka punjenja zrakom pri najvećoj brzini određenoj oznakom brzinske kategorije pneumatika (ETRTO 2003). Pneumatik može nositi više indeksa nosivosti koji prikazuju njegovo dopušteno opterećenje u ovisnosti o brzini kretanja po različitim podlogama (radni strojevi, poljoprivredna i šumska vozila) ili u slučajevima kad se pneumatik upotrebljava zasebno ili u paru (udvojeni kotači), što je čest slučaj kod teretnih cestovnih vozila (kamiona). Intihar (2010) provodeći morfološku analizu guma za šumska vozila različitih proizvođača dolazi do spoznaje da se njihovo dopušteno opterećenje kreće u širokom rasponu od 1000 $\mathrm{kg}$ pa čak do $11.000 \mathrm{~kg}$, odnosno da se vrijednosti indeksa nosivosti kreću u rasponu od 108 do 192.

Često se nosivost pneumatika dodatno označava PRbrojem, koji je u prošlosti predstavljao stvarni broj slojeva platna u karkasi gume. Koliki je stvarni broj slojeva platna u karkasi pneumatika u današnje vrijeme, ovisi o vrsti i kvaliteti materijala od kojih su platna izrađena.

Oznaka brzinske kategorije (eng. Speed Symbol) pneumatika je slovna oznaka koja predstavlja najveću brzinu (slika 


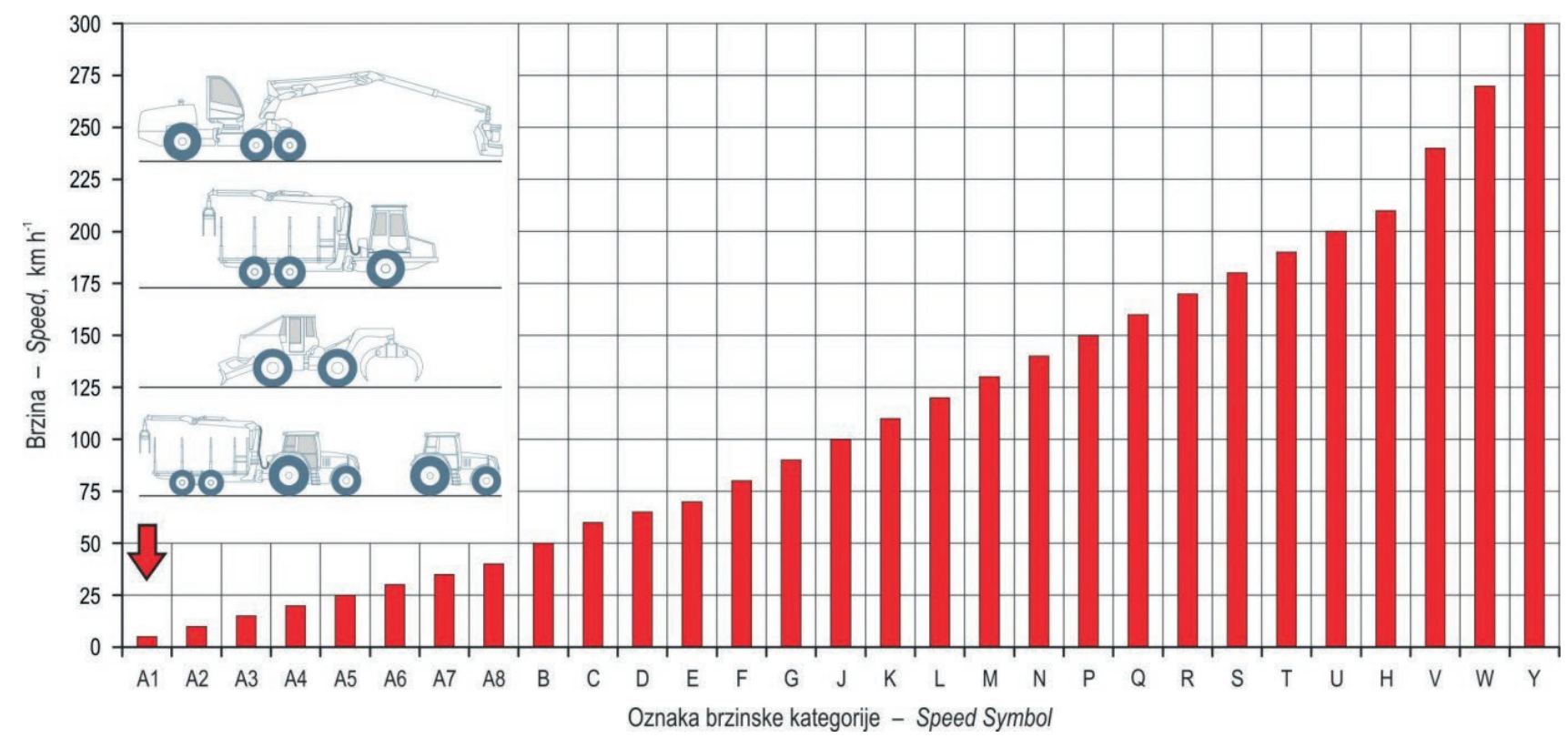

Slika 6. Dijagram oznake brzinske kategorije

Fig. 6 Diagram of Speed Symbol

6) kod koje guma može podnijeti opterećenje koje definira indeks nosivosti pri najvećem tlaku punjenja zrakom (ETRTO 2003).

Iz analize podataka više istraživanja proizvodnosti privlačenja drva skiderima (Đuka 2014) i forvarderima (Poršinsky 2005) provedenim u uvjetima hrvatskog šumarstva može se zaključiti da šumska vozila za privlačenje drva ne premašuju brzinsku kategoriju A1, odnosno $5 \mathrm{~km} / \mathrm{h}$.

Najveće dopušteno opterećenje pneumatika ne smije prekoračiti vrijednost koja odgovara pripadajućem indeksu

\section{Nokian Forest King F 710/45-26.5 20PR 168 A8 / 175 A2}

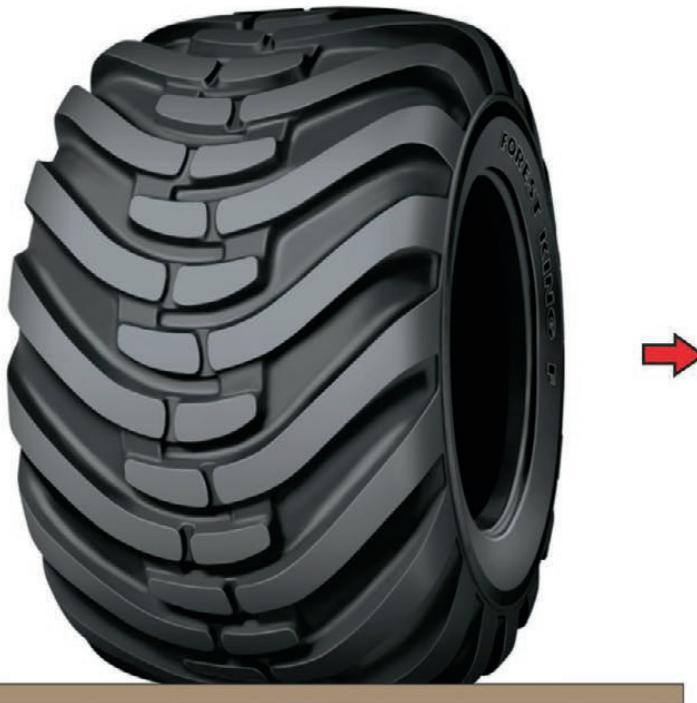

nosivosti na gumi koje proizvođači deklariraju u tablicama promjene nosivosti. Tablica promjene dopuštenoga opterećenja u ovisnosti o tlaku punjenja pneumatika zrakom za različite brzinske kategorije gume (s obzirom na način uporabe vozila, odnosno vrstu podloge po kojoj se vozilo kreće) prikazana je na slici 7. Općenito se može zaključiti da povećanjem tlaka punjenja gume zrakom raste njeno dopušteno opterećenje, a porastom brzine kretanja vozila uz konstantan tlak punjenja zrakom dopušteno opterećenje se smanjuje.

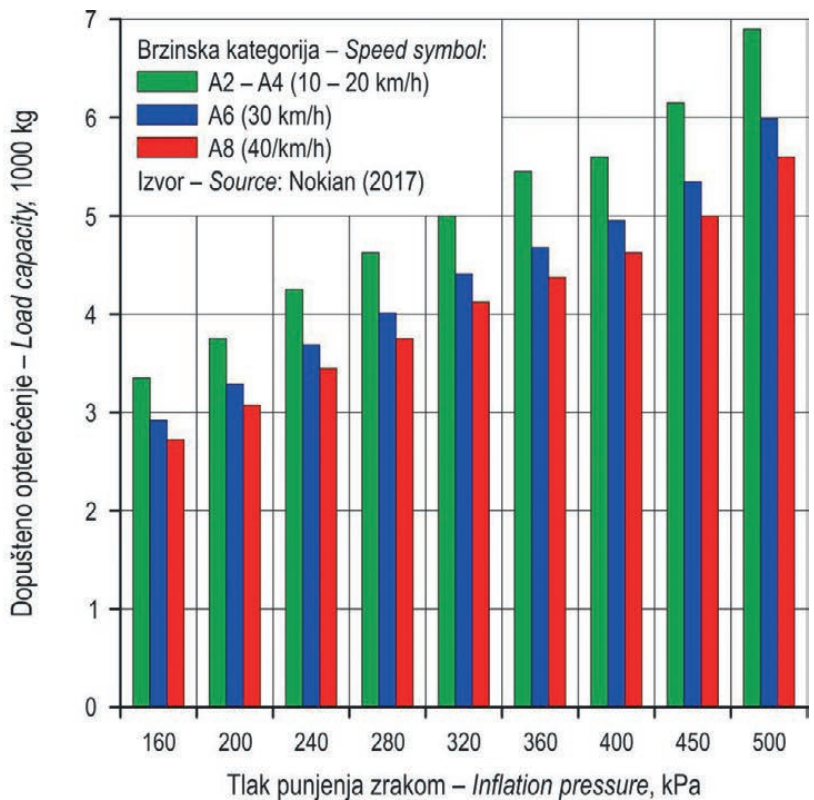

Slika 7. Ovisnost dopuštenog opterećenja gume o tlaku punjenja i brzini kretanja Fig. 7 Load capacity vs. Inflation pressure and Speed 

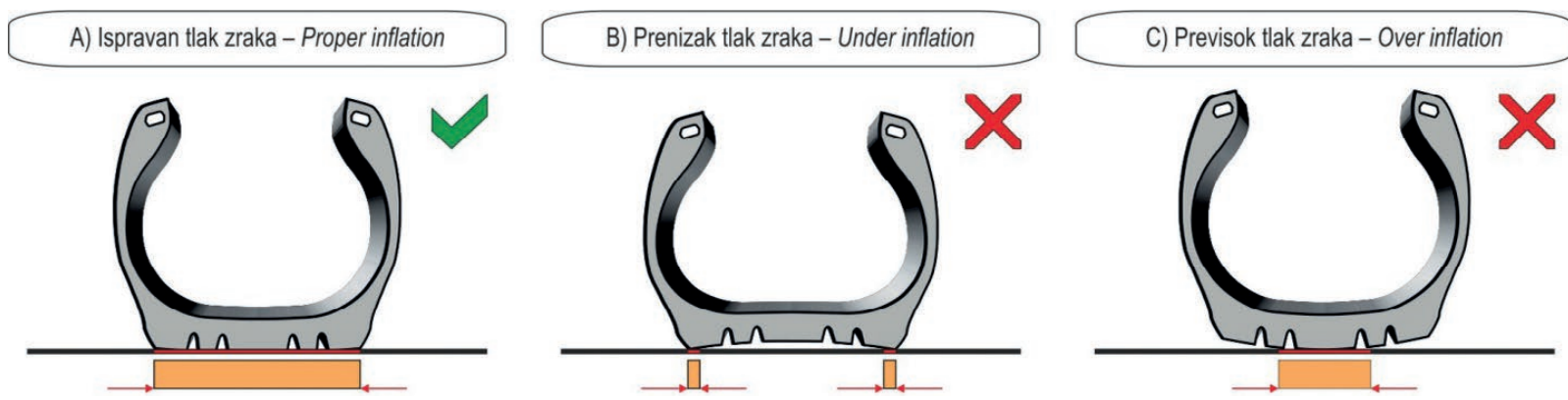

Slika 8. Utjecaj tlaka zraka u pneumatiku na dodirnu površinu s podlogom

Fig. 8 Influence of inflation pressure on the tyre - surface contact area

\subsection{Tlak punjenja zrakom - Inflation pressure}

Zrakje nosivi element pneumatika, pri čemu posebno valja istaknuti da je tlak punjenja pneumatika zrakom ovisan o vanjskoj temperaturi zraka. Porastom vanjske temperature zraka dolazi do rasta tlaka u gumama, a padom vanjske temperature zraka do pada tlaka u gumama.

Važnost kontrole tlaka punjenja pneumatika zrakom je u spoznaji da neodgovarajući tlakovi zraka u gumama utječu na troškove eksploatacije vozila, kroz: povećani intenzitet habanja i kraći životni vijek gume te povećanu potrošnju goriva (Danon i dr. 2014). Isti autori, napominju da neodgovarajući tlak zraka u gumama osim na razdoblje uporabe pneumatika utječe i na intenzitet trošenja njenoga gaznog sloja. Naime, neodgovarajući tlak zraka u gumama, neovisno je li viši ili niži od propisanoga, mijenja oblik i veličinu dodirne površine gume s podlogom što za posljedicu ima neravnomjerno trošenje pneumatika. Ravnomjerno je trošenje po cijeloj širini gazne površine značajno za pneumatike koji su napunjeni ispravnim tlakom zraka (slika 8A). Kod preniskoga se tlaka zraka u pneumatiku brže troše rubovi gazne površine (slika $8 \mathrm{~B}$ ), a kod previsokoga se tlaka zraka u pneumatiku brže troši središnji dio gazne površine (slika 8C).

Posebno valja istaknuti da pri nižem tlaku zraka u pneumatiku od propisanoga (deklariranog) raste potrošnja goriva jer raste otpor kotrljanja, dok pri povišenom tlaku se smanjuje udobnost vožnje jer pneumatik manje apsorbira udarce i neravnine. Smanjenjem se tlaka prenapuhane gume povećava dodirna površina gume i podloge (tla), odnosto raste adhezijsko opterećenje vozila. Pravilno podešenim tlakom zraka u gumama: 1) smanjuje se potrošnja goriva, 2) povećava se vučna sila vozila, 3 ) smanjuje se trošenje gazne površine, ali i 4) smanjuje se sabijanje tla.

Pneumatici vozila općenito, a pogotovo radnih strojeva mogu se puniti i dušikom. Molekule dušika teže prolaze kroz mikroskopske prostore u pneumatiku od zraka koji uz dušik sadrži i druge plinove. Dušik je kemijski inertan plin bez boje, mirisa i okusa. Kisik je s druge strane aktivni plin koji reagira s mnogim materijalima u procesima oksidacije. Osim toga dušik je suhi plin koji ne podržava vlagu, dok kisik u kombinaciji s vodikom daje vodu. Najvažnija je prednost pneumatika punjenih dušikom, u odnosu na one punjene komprimiranim zrakom - manje zagrijavanje tijekom vožnje, a time je osigurana i veća stabilnost vozila. Gume sa zrakom do tri puta se više zagrijavaju, što znači da lakozapaljiva smjesa u unutrašnjosti gume vrlo lako uzrokuje eksploziju. Kad je guma punjena dušikom, tlak se u njoj mijenja sporije, što utječe na njeno habanje te stabilnost vozila, ali i povećanje trajnosti pneumatika. Upravo zbog postojanosti dušika, gumu treba mnogo rjeđe dopunjavati i kontrolirati tlak. Propisano napunjena guma, sa stabilnim tlakom pokazala se pouzdanijom u kritičnim trenucima, jer omogućava lakše kretanje vozila. Prednosti se punjenja pneumatika dušikom očituju kroz: 1) povećani uporabni vijek pneumatika, 2) manju promjena tlaka ovisno o opterećenju kotača i vanjskoj temperaturi, 3) veću sigurnost te 4) rjeđu (nepotrebnu) kontrolu tlaka pneumatika (Danon i dr. 2014).

\subsection{Dezen gazne površine - Tread pattern}

Dezen je pneumatika određen međusobnim rasporedom udubljenja i ispupčenja gazne površine gume. Prostor između dvije susjedne izbočine u dezenu gaznog sloja pneumatika naziva se udubina ili žlijeb, dok se istaka koja strši u odnosu na osnovu dezena gaznog sloja naziva izbočina ili rebro.

Dezeni gaznih površina pneumatika vozila koja se kreću po bespuću, oblikovani su s obzirom na različite zahtijeve ovisno o vrsti i namjeni samih vozila. Osnovni su zahtjevi koji se pred njih postavljaju: 1) trakcija (vuča), 2) flotacija (nošenje) te 3 ) otpornost na zagrijavanje i trošenje (habanje). Slika 9 prikazuje pet osnovnih oblika i tri dubine dezena gazne površine pneumatika radnih strojeva.

Dezen za kamene podloge je oblikovan u svrhu sprječavanja oštećenja gume uzrokovanog oštrim kamenjem. Njegova velika dodirna površina osigurava otpornost na trošenje gume. Tipični žljebovi gume prolaze okomito na smjer kretanja vozila.

Trakcijski dezen je dezen s rebrima ovisno o smjeru kretanja vozila, što je važno pri ugradnji ovih pneumatika na naplatke. Posebno valja istaknuti da pri ugradnji pneuma- 

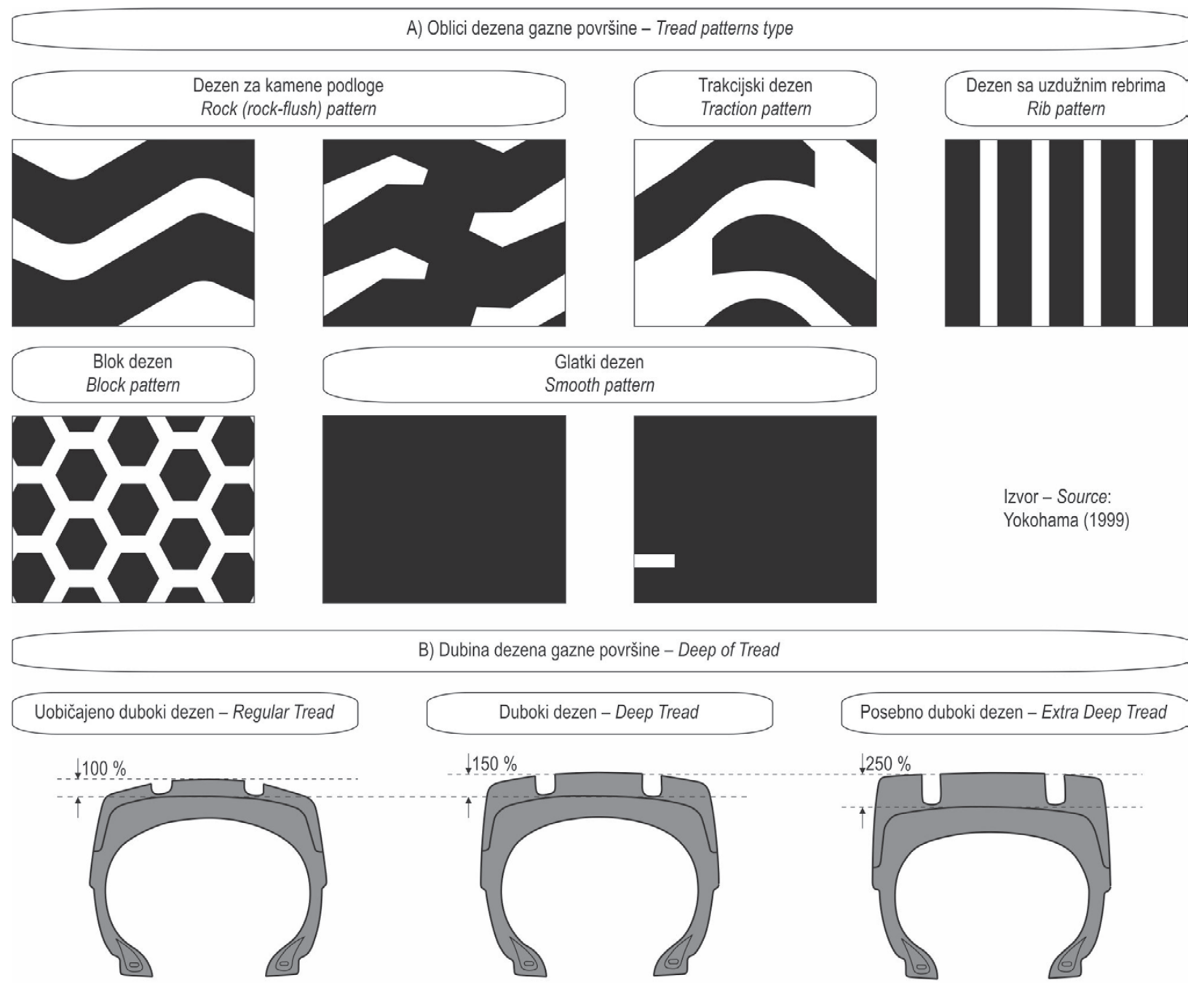

Slika 9. Razredba dezena gazne površine pneumatika radnih strojeva

Fig. 9 Classification of tire tread pattern of working machine

tika s ovim dezenom na pogonske kotače rebra moraju biti u smjeru kretanja, a kod vučenih kotača vozila u suprotnome smjeru.

Za dezen s uzdužnim rebrima značajno je da su rebra i žlijebovi u dezenu paralelni sa smjerom kretanja vozila, što vozila osigurava uzdužnu stabilnost (upravljivost). Ovaj dezen je tipičan za upravljane vučene (slobodno-kotrljajuće) kotače vozila.

Blok dezen je karakteriziran pravilnim gusto postavljenim širokim zaobljenim rebrima. Pod velikim opterećenjem kotača, blok dezen ima veliku dodirnu površinu i mali dodirni tlak na podlogu te predstavlja tipičan »flotacijski« dezen pneumatika.

Glatki dezen je oblikovan za valjke i nema žlijebova, a namijenjen je vozilima za sabijanje i poravnavanje podloge. Ovaj dezen koriste i utovarivači te rudnička vozila, a odlikuje ga visoka otpornost na zagrijavanje i oštećivanje.

Razredbeni kodovi pneumatika za radne strojeve su standardizirani, gume poljoprivrednih i šumskih vozila obuhvaća ISO 4251-4 (2010), a građevinskih strojeva ISO 4250-1 (2014).

Od početaka mehaniziranja šumskih radova do danas, pri opremanju šumskih vozila iskristalizirala su se dva tipična dezena gazne površine pneumatika s dijametralno suprotnim prednostima i nedostatcima, a koji se razlikuju s obzirom na položaj, razmak, visinu i broj rebara (slika 10). Navedene značajke gaznoga sloja pneumatika, presudne su za vučne značajke šumskih vozila pogotovo pri radu na šumskim tlima povećane vlažnosti te ogrančene nosivosti kada dolazi do pojave klizanja kotača ${ }^{1}$.

\footnotetext{
1 Pojava klizanja predstavlja smicanje čestica tla zahvaćenog rebrima pneumatika koja se zasjecaju u tlo pri kontaktu s njegovim površinskim slojem. Pri manjim vučnim silama površinski sloj tla po kojem se kreću pogonski kotači traktora ostaje na svom mjestu, jer je vučna sila traktora manja od kohezijskih sila tla. Proklizavanje kotača nastupa u trenutku kada dolazi do prekoračenja otpora tla na smicanje zahvaćenog rebrima kotača.
} 
Kod trakcijskog dezena gazne površine pneumatika šumskih vozila (slika 10A) rebra su viša i postavljena pod većim kutem u odnosu na smjer kretanja vozila, uz manji broj rebara po opsegu pneumatika sa većom širinom žljebova, što dovodi do: 1) boljeg prijenosa vučnih sila na tlo uz smanjeno klizanje kotača, 2) bolje upravljivosti vozilom te 3) boljeg samočišćenja guma pri kretanju po vlažnim podlogama (Sutherland 2003, Weise 2008). Ronai (1983) napo-

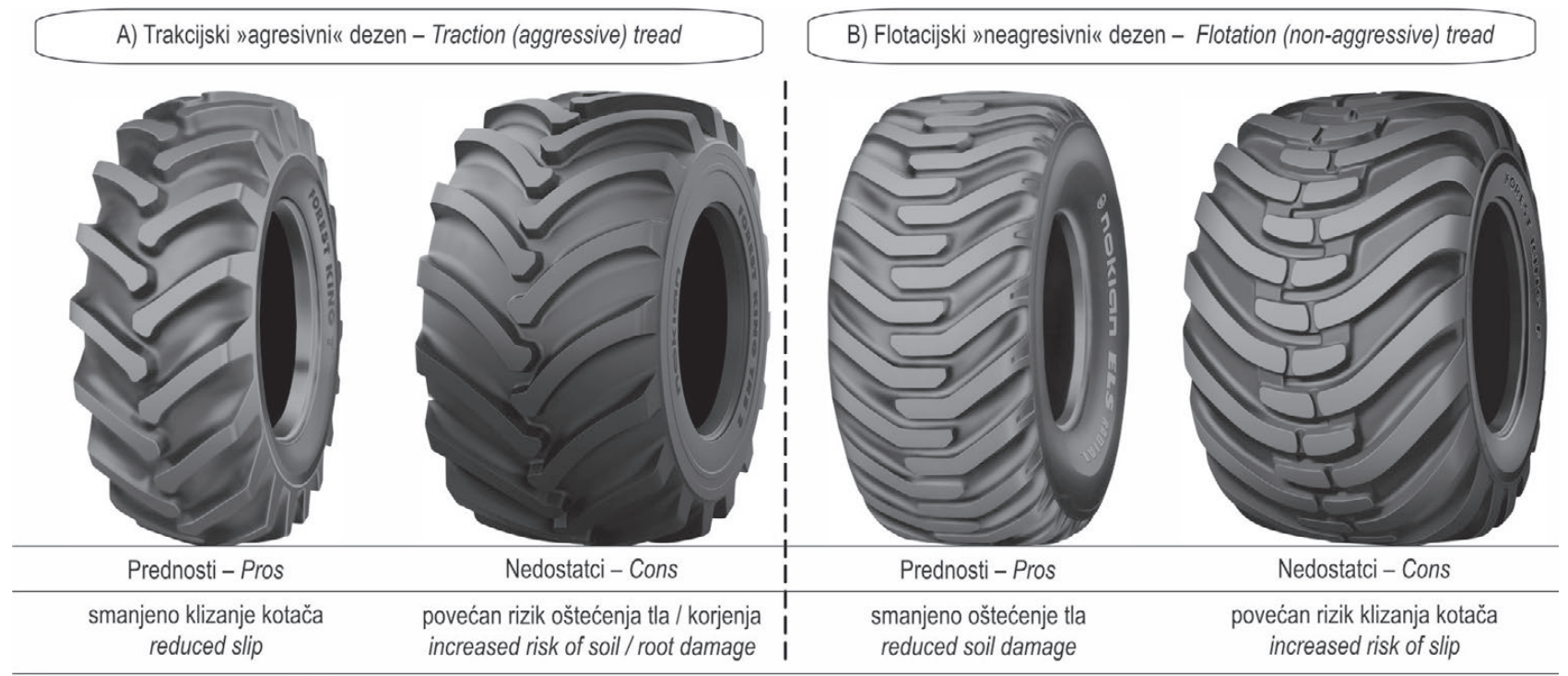

Izvor - Source: Sutherland (2003)

Slika 10. Tipični dezeni gazne površine pneumatika šumskih vozila Fig. 10 Typical tread pattern of forest vehicle tires

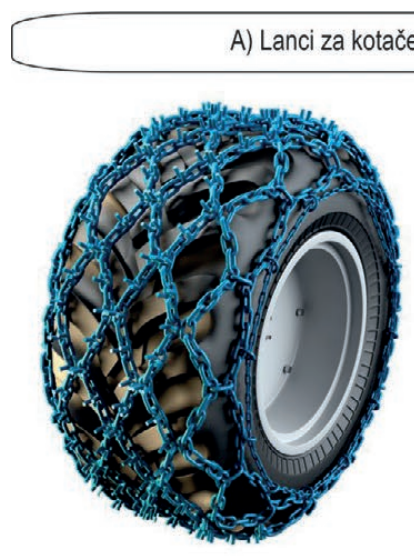

- Wheel chains

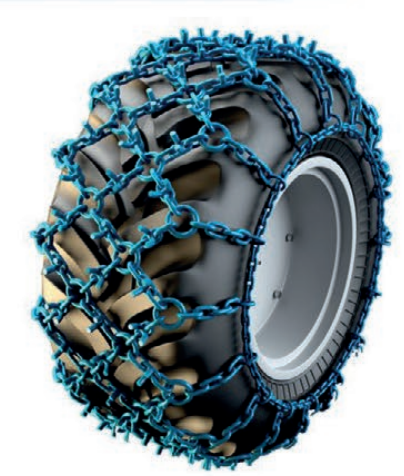

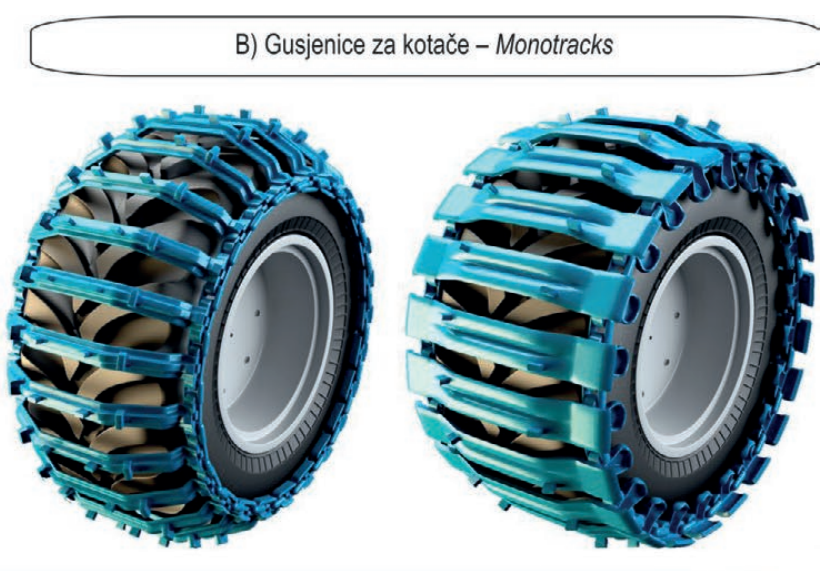

C) Polugusjenice - Tracks (Semitracks)
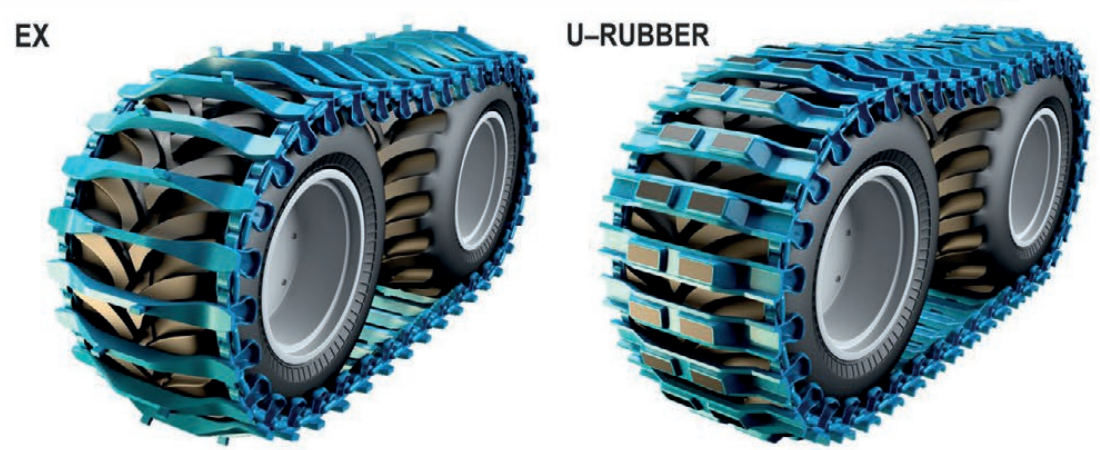

Izvor - Source: Olofsfors (2016)

Slika 11. Dodatno opremanje pneumatika šumskih vozila

Fig. 11 Traction aids of forestry vehicles tyres 


\begin{tabular}{|c|c|c|c|c|c|c|c|}
\hline 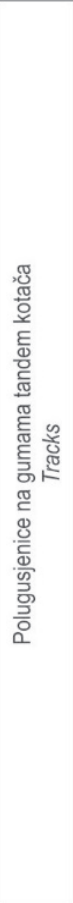 & 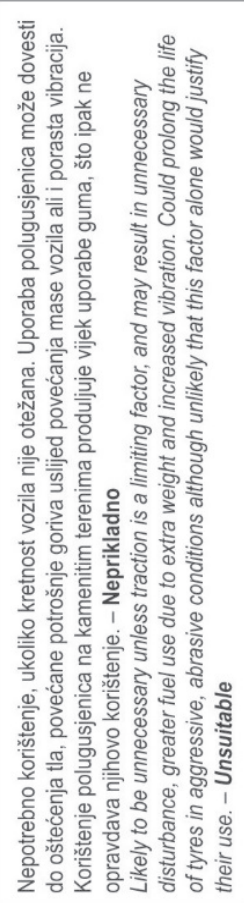 & 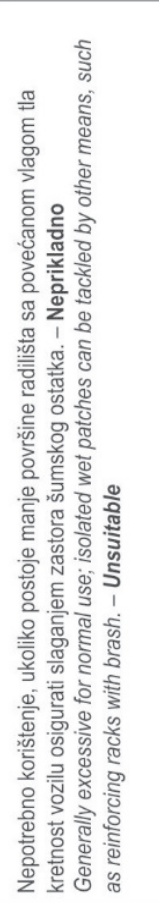 & 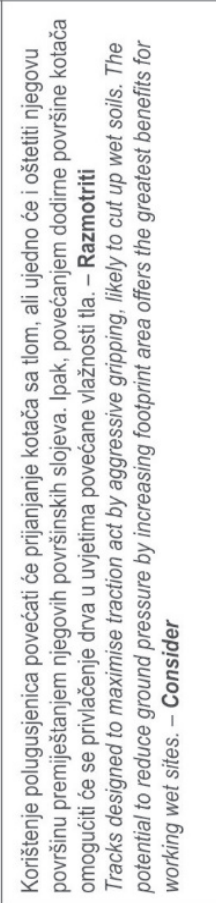 & 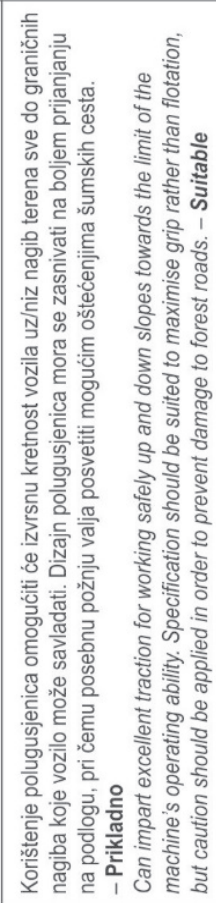 & 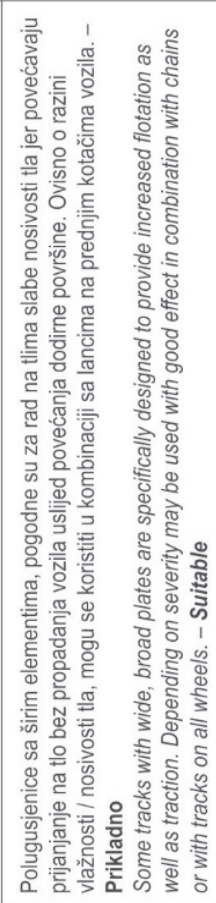 & 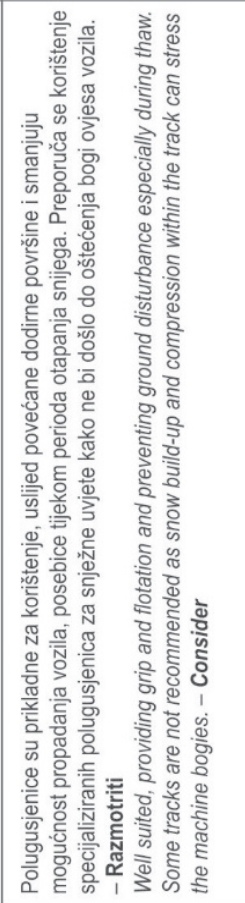 & 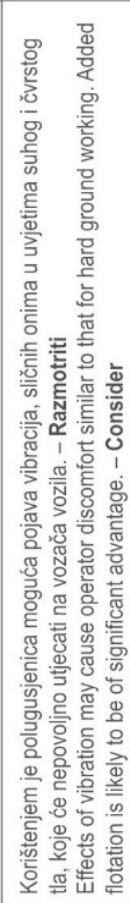 \\
\hline 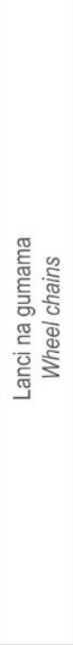 & 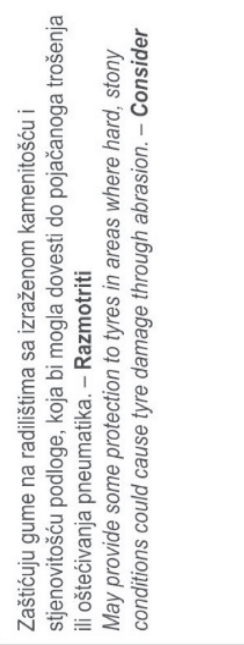 & 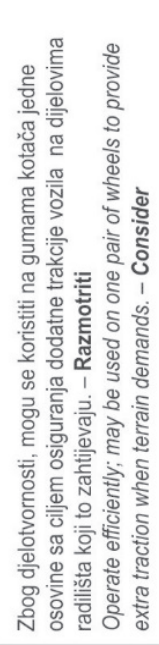 & 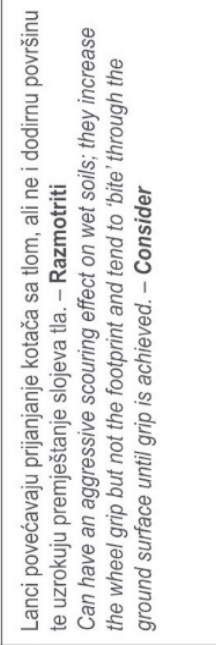 & 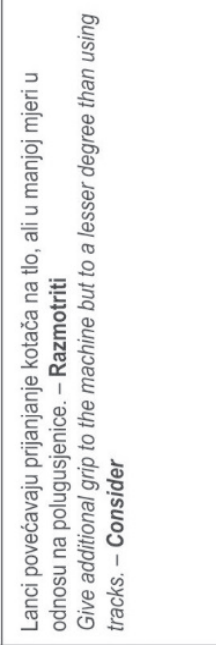 & 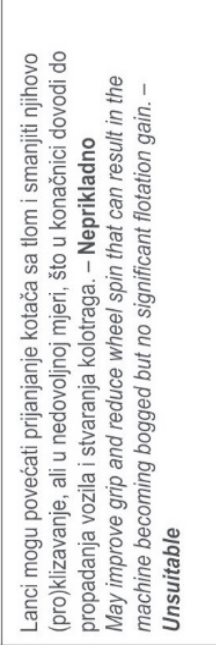 & 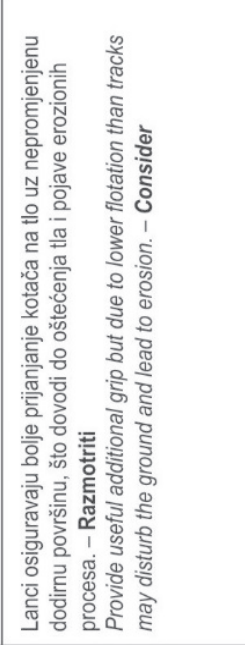 & 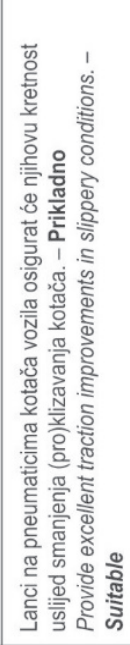 \\
\hline 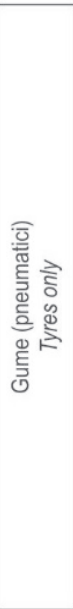 & 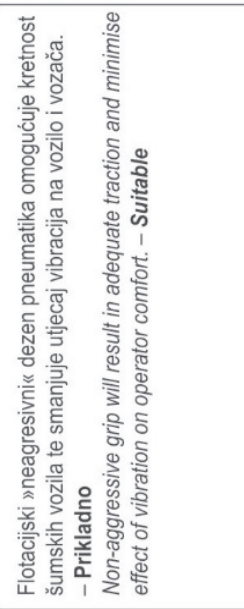 & 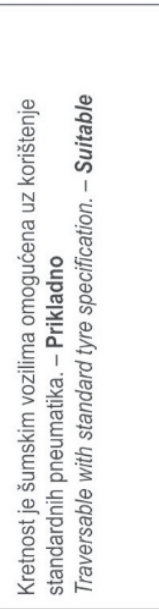 & 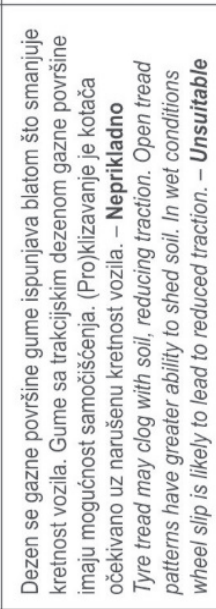 & 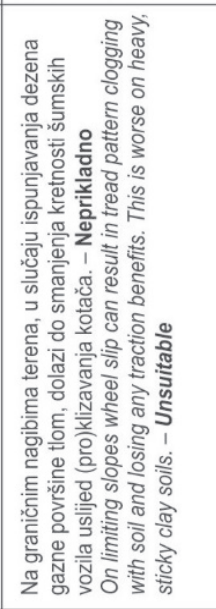 & 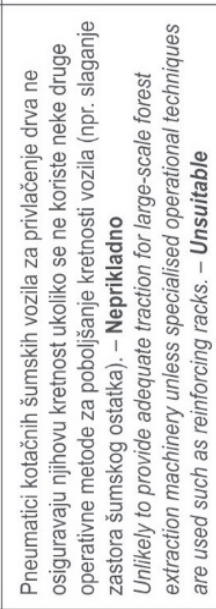 & 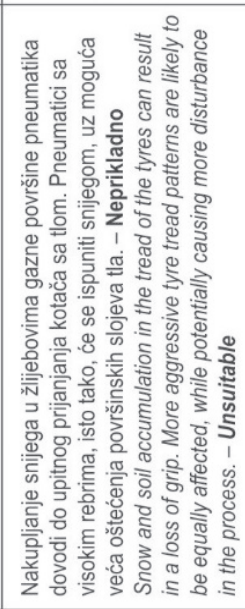 & 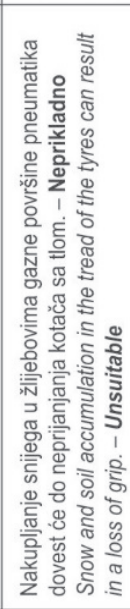 \\
\hline 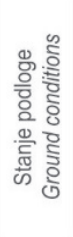 & 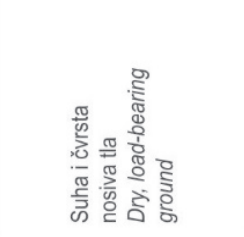 & 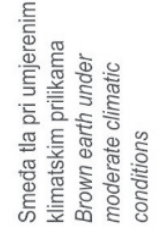 & 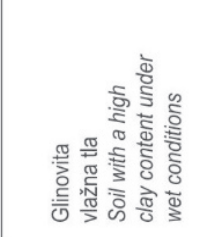 & 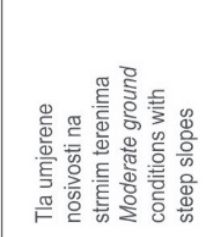 & 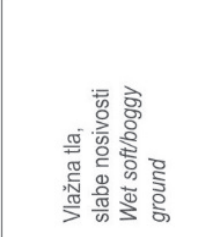 & S. & 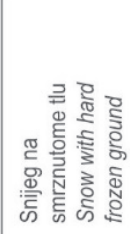 \\
\hline
\end{tabular}


minje da pneumatici sa većom visinom rebara povećavaju otpore kotrljanja kotača, a usljed dubljeg prodiranja u tla ograničene nosivosti mogu uzrokovati veća oštećenja tla.

Za flotacijski dezen gazne površine pneumatika šumskih vozila (slika 10B) značajna su niža rebra koja su postavljena pod manjim kutem u odnosu na smjer kretanja vozila, uz veći broj rebara po opsegu pneumatika s manjom širinom žljebova, što dovodi do: 1) veće dodirne površine i manjih dodirnih tlakova, 2) u uvjetima povećane vlažnosti tla slabijeg samočišćenja, uz povećanu mogućnost klizanja kotača ali i lošijeg prijenosa vučnih sila (Sutherland 2003, Weise 2008). Ovako postavljena rebra, i pored lošije upravljivosti vozilom i slabijeg samočišćenja, ostvaruju zadovoljavajuću trakciju na sušim tlima koja se ne lijepe te ne ostaju u žljebovima među rebrima gazne površine pneumatika šumskih vozila (Križnar 1978). Zakrivljavanjem rebara u području prelaska gazne površine i ramena pneumatika one postaju pogodne za prihvat polugusjenica.

\section{DODATNO OPREMANJE PNEUMATIKA ŠUMSKIH VOZILA TRACTION AIDS OF FORESTRY VEHICLES TYRES}

U ograničenim uvjetima nosivosti podloge, kretanjem šumskih vozila dolazi do oštećivanja (sabijanja) šumskog tla (Ilintsev i dr. 2018, Solgi i dr. 2018, Solgi i dr. 2019A, Solgi i dr. 2019B), čiji su osnovni uzroci visoki dodirni tlakovi (Marusiak i Neruda 2018, Labelle i Jaeger 2019, Labelle i Lemmer 2019) i klizanje kotača (Cudzik i dr. 2018, Haas i dr. 2016). Posebno valja istaknuti da je klizanje kotača pri uporabi kotačnih šumskih vozila na tlima ograničene nosivosti njihov ograničavajući čimbenik kretnosti (Sever 1980).

S ciljem osiguranja kretnosti šumskih vozila na slabo nosivim podlogama, ali i zaštite šumskog tla od oštećivanja, šumska se vozila dodatno opremaju: lancima (slika 11A) i gusjenicama za kotače vozila (slika 11B), odnosno polugusjenicama za udvojene kotače u tandem rasporedu (slika 11C).

Korištenjem lanaca ne povećava se dodirna površina, već se reducira klizanje kotača na nenosivim podlogama, odnosno zaštićuju se gume na kamenitim podlogama (Ireland 2006). Isti autor, navodi da opremanje šumskih vozila gusjenicama za kotače, doprinosi smanjenju klizanja, uz relativno malo povećanje dodirne površine.

Poršinsky i dr. (2011) navode višestruke koristi opremanja kotača udvojene (bogi) osovine fovardera u ograničenim uvjetima nosivosti podloge: 1) zaštita tla od oštećivanja zbog povećanja površine dodira, odnosno smanjenja dodirnoga tlaka, 2) osiguranje kretnosti vozila smanjenjem klizanja kotača, ali i dubine kolotraga odnosno otpora kotrljanja vozila, 3) osiguranje djelotvornosti izvoženja drva, 4) smanjenje potrošnje goriva zbog smanjenja klizanja kotača, 5) povećanje bočne stabilnosti forvardera pri utovaru i istovaru drva, ali i pri kretanju vozila pogotovo pri radu na nagnutim terenima. Korištenje polugusjenica značajno umanjuje brzinu kretanja šumskih vozila pri radu na tlima zadovoljavajuće nosivosti (Poršinsky 2005). Polugusjenice za šumska vozila, razlikuju se s obzirom na korak zgloba polugusjenice te oblik i širinu pločica polugusjenica (slika 11C), koje su oblikovane za rad na ravnim (ECO-TRACK), nagnutim (EX), odnosno kamenitim terenima (U-RUBBER).

Prednosti i nedostaci uporabe guma na šumskim vozilima te njihovo dodatno opremanje lancima i polugusjenicama prikazano je u tablici 1 . Odluka o izboru opremanja šumskih vozila zahtijeva pažljivo razmatranje mnogih prednosti i nedostataka. Svakako, najbolji izbor opremanja šumskih vozila će često biti kompromis, pogotovo ako postoji heteregenost terenskih čimbenika unutar istog šumskog radilišta/sječine (Ireland 2006).

\section{UMJESTO ZAKLJUČKA INSTEAD OF A CONCLUSION}

Ovaj rad treba pojmiti kao svojevrsnu pomoć šumarskim stručnjacima pri opremanju šumskih vozila pneumaticima, odnosno dodatnom trakcijskom opremom. Svakako treba istaknuti da odabir pneumatika ovisi o: 1) vrsti i namjeni šumskih vozila uslijed njihovih dimenzijskih i konstrukcijskih značajki koje utječu na izbor vrste konstrukcije, dimenzija, indeksa nosivosti te oznake brzinske kategorije pneumatika, 2) terenskim prilikama u kojima se koriste šumska vozila koja prvenstveno utječu na izbor visine rebara te oblika dezena gazne površine.

\section{LITERATURA REFERENCES}

- Cudzik, A., Brennensthul, M., Białczyk, W., Czarnecki, J., 2018: Tractive Performance of Tyres in Forest Conditions - Impact Assessment of Ground and Tyres Parameters. Croat. j. for. eng. 39(1): 85-96.

- Čopec, K., Filipović, D., 2007: Usporedba vučnih karakteristika traktora s novim i poluistrošenim pneumaticima u obradi ilovastog tla. Agronomski glasnik 4: 297-308.

- Danon, G., Petrović, M., Vasić, B., 2014: Pneumatici (Karakteristike - Izbor - Eksploatacija). Institut za istraživanja i projektovanja u privredi, Beograd, 1-212.

- Đuka, A., 2014: Razvoj modela prometnosti terena za planiranje privlačenja drva skiderom. Disertacija, Šumarski fakultet Sveučilišta u Zagrebu, 1-303.

- ETRTO, 2003: Standards Manual. The European Tyre and Rim Technical Organisation, 1-377.

- FAO, 1992: Cost Control in Forest Harvesting and Road Construction. FAO Forestry paper 99, Rome, 1-106.

- Haas, J., Hagge Ellhöft, K., Schack-Kirchner, H., Lang, F., 2016: Using photogrammetry to assess rutting caused by a forwarder - A comparison of different tires and bogie tracks. Soil and Tillage Research 163: 14-20. 
- Hnatko, E., 1977: Motorna cestovna vozila. Tehnička knjiga Zagreb, 1-362.

- Horvat, D., 1993: Prilog proučavanju prohodnosti vozila na šumskome tlu. Disertacija, Fakultet strojarstva i brodogradnje Sveučilišta u Zagrebu, 1-234.

- Ilintsev, A., Nakvasina, E., Aleynikov, A., Tretyakov, S., Koptev, S., Bogdanov, A., 2018: Middle-Term Changes in Topsoils Properties on Skidding Trails and Cutting Strips after Long-Gradual Cutting: a Case Study in the Boreal Forest of the North-East of Russia. Croat. j. for. eng. 39(1): 71-83.

- Intihar, M., 2010: Značilnosti pnevmatik pri spravilu lesa za prilagojene kmetijske traktorje in forvarderje. Diplomsko delo, Univerza v Ljubljani, Biotehniška fakulteta, Oddelek za gozdarstvo in obnovljive gozdne vire, 1-59.

- ISO 4250-1, 2014: Earth-mover tyres and rims - Part 1: Tyre designation and dimensions, 1-24.

- ISO 4251-4, 2010: Tyres (ply rating marked series) and rims for agricultural tractors and machines - Part 4: Tyre classification and nomenclature, 1-3.

- Ireland, D., 2006: Traction Aids in Forestry. Forestry Commission, Technical Note, 13: 1-8.

- Križnar, M., 1978: Kakav pneumatik? Agrotehničar 14(1): 7-8.

- Labelle, E.R., Jaeger, D., 2019: Effects of Steel Flexible Tracks on Forwarder Peak Load Distribution: Results from a Prototype Load Test Platform. Croat. j. for. eng. 40(1): 1-23.

- Labelle, E.R., Lemmer, K.J., 2019: Selected Environmental Impacts of Forest Harvesting Operations with Varying Degree of Mechanization. Croat. j. for. eng. 40(2): 239-257. https://doi. org/10.5552/crojfe.2019.537

- Matas, J., 2017: Gume kotača šumskih vozila. Diplomski rad, Šumarski fakultet Sveučilišta u Zagrebu, 1-48.

- Marusiak, M., Neruda, J., 2018: Dynamic Soil Pressures Caused by Travelling Forest Machines. Croat. j. for. eng. 39(2): 233245.

- Nokian, 2017: Technical Manual - Heavy Tyres, Truck and Bus Tyres, 1-385.

- Olofsfors, 2016: Product catalog - Welcome to Our Teritory, Olofsfors, 1-43.

- Poršinsky, T., 2005: Djelotvornost i ekološka pogodnost forvardera Timberjack 1710 pri izvoženju oblovine iz nizinskih šuma
Hrvatske. Disertacija, Šumarski fakultet Sveučilišta u Zagrebu, $1-170$.

- Poršinsky, T., Stankić, I., Bosner, A., 2011: Ecoefficient Timber Forwarding Based on Nominal Ground Pressure Analysis. Croat. j. for. eng. 31(1): 345-356.

- Ronai, Đ. M., 1983: Teorija kretanja van tvrdih puteva. Fakultet tehničkih nauka Univerziteta u Novom Sadu, 1 - 324.

- Sever, S., 1980: Istraživanje nekih eksploatacijskih parametara traktora kod privlačenja drva. Doktorska disertacija, Šumarski fakultet Sveučilišta u Zagrebu, 1-301.

- Solgi, A., Naghdi, R., Labelle, E.R., Tsioras, P.A., Salehi, A., 2018: Comparison of Sampling Methods Used to Evaluate Forest Soil Bulk Density. Croat. j. for. eng. 39(2): 247-254.

- Solgi, A., Naghdi, R., Labelle, E.R., Behjou, F.K., Hemmati, V., 2019: Evaluation of Different Best Management Practices for Erosion Control on Machine Operating Trails. Croat. j. for. eng. 40(2): 319-326. https://doi.org/10.5552/crojfe.2019.532

- Solgi, A., Naghdi, R., Zenner, E.K., Tsioras, P.A., Hemmati, V., 2019: Effects of Ground-Based Skidding on Soil Physical Properties in Skid Trail Switchbacks. Croat. j. for. eng. 40(2): 341350. https://doi.org/10.5552/crojfe.2019.535

- Sutherland, B.J., 2003: Preventing Soil Compaction and Rutting in the Boreal Forest of Western Canada: A Practical Guide to Operating Timber-Harvesting Equipment. FERIC Advantage 4(7): $1-52$.

- Španiček, Đ., 2011: Otac gume Charles Goodyear. Polimeri 32(1): 30.

- Španiček, Đ., 2012: Tko je pronalazač gumenih pneumatika? Polimeri 33(2): 69-70.

- Štrumberger, N., Džanić, H., 1991: Automobilske gume i njihovo održavanje. Promet 3(4): 175-181.

- Štrumberger, N., 2005: Tehnologija materijala I. Udžbenik, Fakultet prometnih znanosti Sveučilišta u Zagrebu, 1-412.

- Weise, G., 2008: Entwicklung und Einsatz von Forstreifen. LWF aktuell 67: 24-27.

- Wong, J.Y., 2001: The Theory of Ground Vehicles. John Wiley and Sons, 1-535.

- Yokohama, 1999: Off-the-Road Tires Handbook. The Yokohama Rubber Co., 1-90.

\section{SUMMARY}

Wheel tires are the only contact of forest vehicles with the ground through which forces or loads are transmitted to the forest floor.

Forestry experts therefore need to select tires carefully when equipping vehicles based on their dimensional and constructional characteristics as well as ground and stand conditions. The basic characteristics of tires are processed through their construction, dimensions and marking, load index, speed symbol, inflation pressure and tread pattern. Due to the frequently increased moisture of forest soils and their limited bearing capacity, special attention is paid to the additional equipment of forest vehicle tires with chains, ie semi-tracks in order to reduce forest soil damage and gain efficiency.

KEY WORDS: tyre, chain, semi-track 